\title{
Long-term ecological research on Italian forest ecosystems: perspectives and conclusions
}

\author{
Rosario MOSELLO*, Bruno PETRICCIONE ${ }^{1)}$ and Aldo MARCHETTO
}

CNR Institute of Ecosystem Study (ISE), Research Unit of Hydrobiology and Freshwater Ecology, L.go V. Tonolli 50, 28922

Verbania Pallanza, Italy

${ }^{1)}$ Ministry for Agriculture and Forestry Policy, National Forest Service, CONECOFOR Service, Via Carducci 5, I-00187 Roma, Italy

*e-mail corresponding author: r.mosello@ise.cnr.it

\begin{abstract}
The paper summarises the contents of the present volume devoted to forest research in Italy, within the National Programme for Forest Ecosystem Monitoring (CONECOFOR), part of the Level II forest monitoring, and other linked regional and provincial monitoring activities. The coordination of the project, through a National Focal Centre and a Task Force for the Integrated and Combined Evaluation of results, made up of the foremost Italian experts working in the field, is outlined. No clear signals of strong negative impacts emerge from the papers, although the results of several studies indicate nitrogen and ozone as possible causes of disturbances in a number of plots. The effects of the deposition of acidity are largely buffered by the nature of the soils, while nitrate is leached from the plots where runoff is analysed, indicating $N$ saturation of soils. This paper describes the main activities of the Task Force as regards data validation and elaboration, aimed at providing reliable information leading to sustainable forest management in Italy as well as making a useful contribution to international activities in a Pan-European context.
\end{abstract}

Key words: forest, intensive studies, Italy, CONECOFOR, permanent plots

The papers collected in this volume provide a comprehensive view of the present situation of studies and monitoring activities in Italian forests, particularly the National Programme for Forest Ecosystem Monitoring (CONECOFOR) carried out in the framework of the Level II forest ecosystems monitoring (Regulation EC n. 1091/94) and the UN-ECE International Co-operative Programmes on Assessment and Monitoring of Air Pollution Effects on Forests (ICP Forests) and on Integrated Monitoring of Air Pollution Effects on Ecosystems, part of the Convention on Long Range Transboundary Air Pollution (LRTAP).

The CONECOFOR programme has been co-ordinated in Italy since 1995 by a National Focal Centre (NFC) under the aegis of the Ministry for Agriculture and Forestry Policy - National Forest Service, which works, as regards the management of specific plots, with the Forestry Departments of the Regions of Tuscany, Lombardy and Sicily, and the Autonomous Provinces of Trento and Bolzano/Bozen. The present (2002) network is based on 28 permanent plots (PMPs, Tab. 1); 11 plots are also classed as "biomonitoring sites" in the framework of the ICP-IM (Petriccione \& Pompei 2002). The PMPs are representative of larger natural and seminatural forest ecosystems, in different Italian geographical and climatic conditions: the Alps, the North and Central plain areas, the Apennines from Liguria to Calabria, the islands of Sicily and Sardinia (Fig. 1).

The main dominant species are Fagus sylvatica (10 plots), Picea abies (6), Quercus cerris (5), Quercus ilex
(4), Quercus petraea (1), Quercus robur (1) and Abies alba (1).

According to a systematic and syntaxonomical description of the plant communities represented (Petriccione 2002), the CONECOFOR PMPs cover 17 plant communities, grouped in three different classes. The best represented class is that of the Central-European broad-leaved deciduous forests (Querco-Fagetea); the second is characterised by the Boreal coniferous forests (Vaccinio-Piceetea), while the poorest class is that of the Mediterranean evergreen forests (Quercetea ilicis). A preliminary analysis of species richness at community level shows that the lowest values occur in beech forests and the highest in Turkey oak forests; spruce forests on the other hand are divided into two groups, the first comprising the secondary type (with high diversity values) and the second comprising the primary type (with relatively low diversity values). According to a preliminary analysis of the main dynamic tendencies, fluctuation is the commonest ongoing process (mostly occurring in beech and primary spruce forests). Regeneration is also widespread, following the recent general decline of wood exploitation and coppicing. Regression and degeneration have been observed in a few plots, but have become the rule only in some Quercus cerris and Quercus ilex dominated forests. The first changes in the vegetation seen during the first 6-7 years of investigation are slight and of very low significance: more survey time is required to evaluate the ongoing trends.

All the mandatory variables of the Level II investigations have been progressively measured since 1995,

Paper prepared within the CONECOFOR programme, by the contract with the Ministry for Agriculture and Forestry Policy - National Forest Service, Italy. CONECOFOR is part of the Pan-European Level II Intensive Monitoring of Forest Ecosystem and is co-sponsored by the European Commission. 
Tab. 1. Italian Permanent Plots in the CONECOFOR network. Acronyms: CFS: Corpo Forestale dello Stato; CR-ENEA: Centro Ricerche Ente Nazionale Energie Alternative; * Regional and Provincial Administrations.

\begin{tabular}{|c|c|c|c|c|c|c|}
\hline Code & Name & Altitude $\mathrm{m}$ a.s.l. & Lithological substrate & Dominant species & Managing agency & ICP-IM code \\
\hline 01-ABR1 & Selva Piana & 1500 & Limestone & Fagus sylvatica & CFS & IT05 \\
\hline 02-BAS1 & Monte Grosso & 1125 & Sandstone Flisch & Quercus cerris & CFS & - \\
\hline 03-CAL1 & Piano Limina & 1100 & Granite & Fagus sylvatica & CFS & IT06 \\
\hline 04-CAM1 & Serra Nuda & 1175 & Limestone & Fagus sylvatica & CFS & - \\
\hline 05-EMI1 & Carrega & 200 & Ancient alluvium & Quercus petraea, Quercus cerris & Regional Park & IT07 \\
\hline 06-EMI2 & Brasimone & 975 & Sandstone & Fagus sylvatica & CR-ENEA & IT08 \\
\hline 07-FRI1 & Bosco Boscat & 6 & Recent alluvium & Quercus robur, Carpinus betulus & CFS & - \\
\hline 08-FRI2 & Tarvisio & 820 & Phyllites & Picea abies & CFS & - \\
\hline 09-LAZ1 & Monte Rufeno & 690 & Sandstone Flisch & Quercus cerris & CFS & IT09 \\
\hline 10-LOM1 & Val Masino & 1190 & Granite & Picea abies & Region & IT10 \\
\hline 11-MAR1 & Roti & 775 & Limestone & Quercus cerris & CFS & IT11 \\
\hline 12-PIE1 & Val Sessera & 1150 & Mica schist & Fagus sylvatica & Region & - \\
\hline 13-PUG1 & Foresta Umbra & 800 & Limestone & Fagus sylvatica & CFS & - \\
\hline 14-SAR1 & Marganai & 700 & Sandstone & Quercus ilex & Region & - \\
\hline 15-SIC1 & Ficuzza & 940 & Sandstone & Quercus cerris & Region & - \\
\hline 16-TOS1 & Colognole & 150 & Gabbro & Quercus ilex & Region & IT12 \\
\hline 17-TRE1 & Passo Lavazè & 1775 & Granite & Picea abies & Province & IT03 \\
\hline 18-UMB1 & Pietralunga & 725 & Sandstone Flisch & Quercus cerris & CFS & - \\
\hline 19-VAL1 & La Thuile & 1740 & Gneiss, mica schist & Picea abies & Region & IT13 \\
\hline 20-VEN1 & Pian di Cansiglio & 1100 & Limestone & Fagus sylvatica & CFS & - \\
\hline 21-ABR2 & Rosello & 960 & Sandstone, limestone & Abies alba, Quercus cerris & Regional Reserve & - \\
\hline 22-LAZ2 & Monte Circeo & 190 & Limestone & Quercus ilex & CFS & - \\
\hline 23-LOM2 & Giovetto & 1260 & Shales, limestone & Picea abies & Region & - \\
\hline 24-LOM3 & Valsassina & 1250 & Sandstone, limestone & Fagus sylvatica & Region & - \\
\hline 25-TOS2 & Cala Violina & 30 & Sandstone & Quercus ilex & Region & - \\
\hline 26-TOS3 & Vallombrosa & 1170 & Sandstone & Fagus sylvatica & Region & - \\
\hline 27-BOL1 & Renon & 1740 & Morain, quartz porphyry & Picea abies & Province & IT01 \\
\hline 28-LIG1 & Monte Zatta & 1290 & Sandstone & Fagus sylvatica & Region & - \\
\hline
\end{tabular}

in strict accordance with EU Regulation n. 1091/94 and ICP Forests protocols, and following the guidelines for participation in intercomparison exercises and harmonisation activities organised at international level. Scientists and institutions with expertise in the various fields, and with experience of participating in international projects, were appointed to undertake a range of studies, under the coordination of the NFC. A web site (www.corpoforestale.it/conecofor) and an introductory book (Allavena et al. 2001) provide more detailed information on the organisation of the project in Italy and its links with the international co-ordination centre.

Of the mandatory variables, meteorology and climatology are studied in 16 PMPs, representative of different geographic conditions, through the measurement of air temperature, solar radiation, amount of precipitation and windiness (Amoriello \& Costantini 2002). Measurements are made in the PMPs, under the canopy, and in the open field. Data collected in the five year period 1997-2001 were used to establish the correlation between the geomorphological and the climatic conditions of the areas. Data referring to the amount of precipitation are also used to evaluate the flux of ions from the atmosphere to the plots, along with sampling and chemical analyses of open field, throughfall and, in beech stands, stemflow deposition. Results reveal marked differences among the plots, related both to natural processes (e.g. sea-salt contribution, volcanic emissions from Mt Etna) and to anthropogenic emissions (Mosello et al. 2002). A general feature of most of the PMPs is the high deposition of nitrogen, exceeding critical load values, with peak values in Northern Italy. Surface water chemistry, monitored in five plots, confirms $\mathrm{N}$ saturation of the soils, showing nitrate leaching proportional to $\mathrm{N}$ exceedances. On the other hand the deposition of acidity is generally buffered by the soils, which in most of the PMPs are made up of highly neutralising rock.

Soil composition was examined in 70 plots of the Level I investigation, including 20 CONECOFOR PMPs (Alianiello et al. 2002). Results reveal no soils with $\mathrm{pH}<3$ and few with $\mathrm{pH}$ values between 3.0-3.5; furthermore, the soils with low $\mathrm{pH}$ are naturally acid, due to their parent material. Base saturation and the sum of exchangeable base cations in the mineral layer show that there are hardly any soils in poor health, and that the availability of nutrients (particularly nitrogen and phosphorus) is on the whole sufficient.

More detailed studies on soil and soil solutions are being carried out in a PMP in the Central Apennines (ABR1, Tab. 1), under a Fagus sylvatica stand (Cecchini et al. 2002). Results show acid pulses evident mostly below the organic horizons, in relation with a marked release of nitrate from the litter; some events were not always immediately neutralised by basic cations, but were however neutralised in the surface min- 


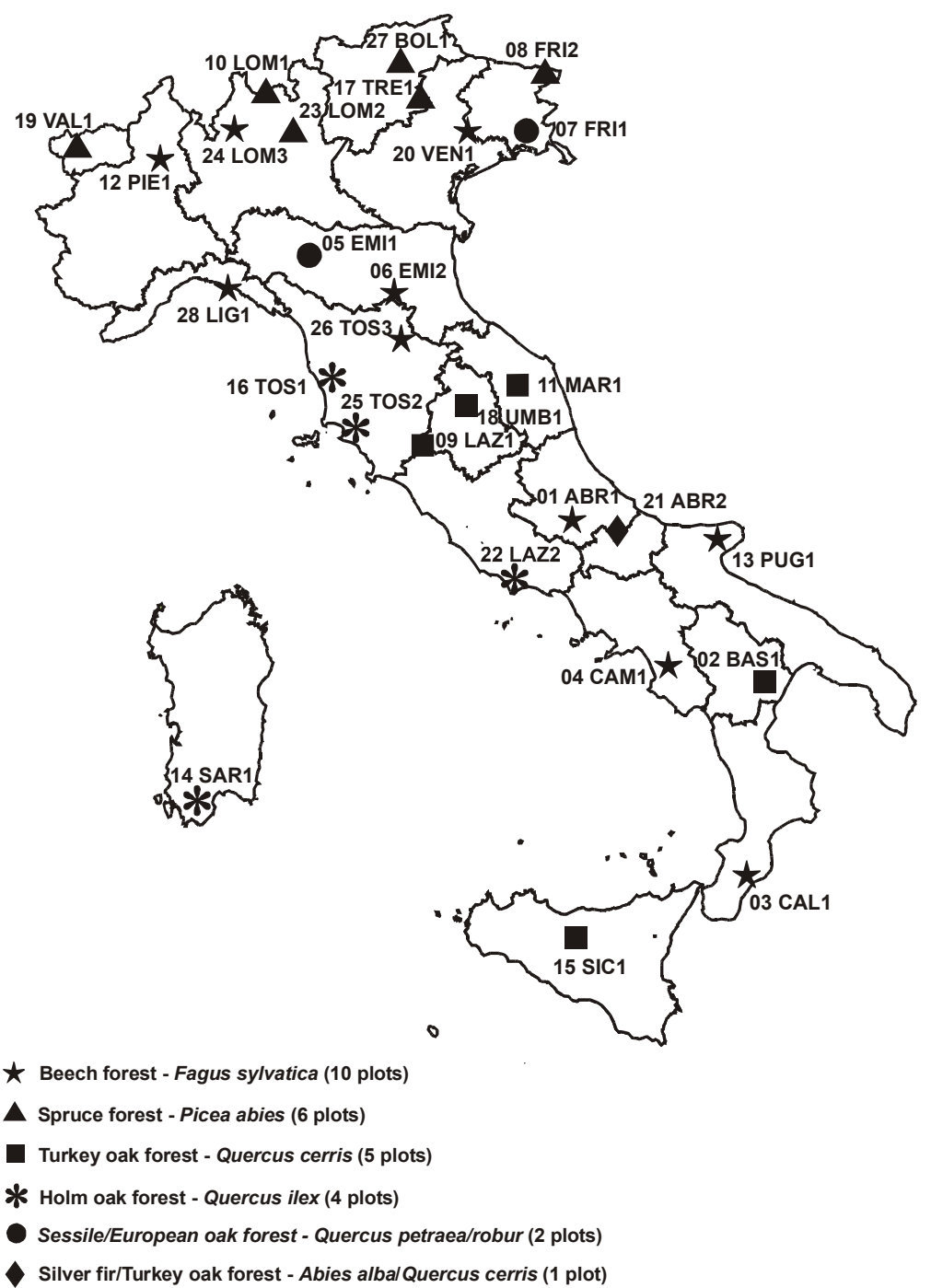

Fig. 1. Geographical location of the National Network CONECOFOR permanent plots.

eral horizons, within $15 \mathrm{~cm}$ depth. Studies on soil solutions are currently being performed also in a second PMP, in Central Italy (LAZ1, Tab. 1).

Crown condition assessment has been carried out since 1996. Continuing in greater detail the studies included in the Level I monitoring (Bussotti et al. 2002). A large number of parameters (both mandatory and optional according to the European common manual) are considered. Quality Assurance procedures have been used continuously throughout the study period, with a consequent increase in the level of reproducibility of the results. A composite index to describe the overall condition of the crowns was elaborated, using a selection of the most indicative parameters. The first results indicate that the short-term changes in crown condition are related to leaf damage (insects and pest, meteoric events).

Annual litter production and leaf area index (LAI) were measured in 19 PMPs to characterise crown and canopy characteristics (Cutini 2002). The low value of the within-plot mean relative standard deviation accounted for a sampling error, which seems to be sufficiently accurate to detect changes in litter production throughout the years. The existence of significant differences both in leaf litter and total litter production seems to attribute to the factor "year" a driving role in determining changes in litter production and LAI. Temporal intermittence in data collection, together with the shortness of the monitoring period, make it difficult either to speculate or to arrive at definitive conclusions on changes in litter production due to time-dependent factors and possible integrated analyses with results emerging from other research actions (i.e. meteorology, crown condition, increment, ground vegetation).

Forest mensuration provided the set of growth descriptors for Level II plots at 1997 and 2000 (Fabbio \& Amorini 2002). The diversity of forest ecosystems included in the network design is well-recorded by tree species and structural characteristics at plot level; forest 
management and stand origin, coppice or high forest, being the main discriminants. It produces a number of consequences such as prevailing age classes, tree densities and differences in tree population dynamics (ingrowth and regular mortality), which affect the observed growth. To this end, the database was arranged per forest type and parameters analyzed within each subset. The inner structure of growth was focused on in particular by stratifying the tree population in each plot and calculating the relative allocation rates. This made it possible to explore the within-and-between variability and to improve the consistency of growth indicators.

Tree ring growth was analysed in five Turkey oak plots, characterised by a different age and management system (Manetti 2002). The existing relationships between dominant and codominant trees were highlighted and the trend typical of the species defined. In the mean site chronologies, a few parameters such as age, site index and silvicultural management were identified as the main factors driving both stand structure and productivity. The juvenile phase is always characterised by high growth values and a short-wave trend; growth then decreases slowly following a more regular pattern. The site index drives the length and frequency of competition cycles, social arrangement, and recovery after disturbances. Silvicultural practices interact with environmental and biological factors by modelling stand structure and reducing competition level, thus determining abrupt, repeated releases of growth trend.

In addition to the technical and scientific information provided by the international co-ordination centres, the CONECOFOR project was able to take advantage of the expertise and data deriving from regional projects in Lombardy, Tuscany and in the Provinces of Trento and Bolzano/Bozen. These studies are still in progress, coordinated by the Regional/Provincial Forestry Boards, and the information they provide is a valuable addition to the national project. Their main aims and their links with the CONECOFOR programme are described in four papers in this volume.

The studies begun in Lombardy (Balestrini et al. 2002) in 1987 considered a number of plots; two of them, located in the Central Alps, have since 1994 been the focus of special interest, and show different levels of damage to vegetation. The most marked living crown damage was shown to be related to a higher contribution of dry atmospheric deposition of acidity and nitrogen, which produce greater canopy leaching of $\mathrm{Ca}, \mathrm{K}$ and weak organic acids. The excess deposition of nitrogen was demonstrated from a watershed budget; the same study, using Stoddard's approach (Stoddard \& Traaen 1995), highlighted nitrogen saturation of the soil.

Another important regional forest study is that of Tuscany (Bartolozzi et al. 2002). Monitoring started in 1987 in the framework of the Level I network, and continued under the National Programme from 1996, with the establishment of three PMPs. Among the aims of the programme in Tuscany, together with the acquisition of data on the condition of health and trends in forested ecosystems, is to establish connections with other regional information systems, with a view to producing information of use in planning a Sustainable Forest Management programme.

Other important local studies have been carried out since 1992 in the autonomous provinces of Trento and Bolzano/Bozen, in the North-western Alps (Ambrosi et al. 2002). Four plots of semi-natural forest were considered, two in the Central-European belt (dominated by Quercus pubescens), and two in the Boreal belt (dominated by Picea abies) which were added to the CONECOFOR National Programme in 1995 and 2001. The interdisciplinary programmes covered meteorology, anthropogenic stresses (air pollution and precipitation chemistry), foliage chemistry, crown condition and mycological analysis. High levels of damage were never detected and defoliation and discoloration did not indicate a situation of risk. Only ozone showed higher values than normal, but no correlation with any forest symptoms was detected.

The chemistry of atmospheric deposition in these plots is the object of particular study (Marchetti et al. 2002); data have been available since 1985 and 1990 for bulk and wet-only samples, respectively. The present values of mineral acidity are low, with median values ranging between 5.1 and 5.7. The long term trend shows a marked decrease of sulphate and acidity, while slight and statistically insignificant variations were detected for ammonium and nitrate. The result of this is an increase in the importance of nitrogen species, while the low acidity is in agreement with the absence of major damage to the forest ecosystems.

Besides the organisation of experimental measurements, the CONECOFOR project includes a programme of data evaluation, which will create a database for data management and a Task Force for the Integrated and Combined (I\&C) evaluation of the results. Up to now the database has been designed for the storage, validation and elaboration of ground vegetation data, with special attention being paid to the homogeneity and comparability of diachronic data records, essential for long-term evaluation. Further data sets are currently being included (Canullo et al. 2002).

The I\&C Task Force is made up of the foremost experts of the institutions in charge of the experimental activities within the CONECOFOR programme, together with experts from the NFC. The primary purposes of the data elaboration are (i) the evaluation of risk status in relation to air pollution, (ii) the quantification of the ecosystem's status and changes and (iii) the evaluation of the relationship between anthropogenic pressure and status indicators through time (Ferretti 2002). Other aspects considered are the overall quality of the data and the propagation of errors in the evaluation of synthesis measurements, the coordination of the 
institutions performing different researches, and collaboration with the international co-ordinating centres ICP Forests and ICP IM. A further activity is the publication of the results, for example in a special issue of the journal "Annali di Selvicoltura" (1999) and in the present volume. A series of special monographs summarising the results of the various researches is planned; the first, on ozone, is in preparation (Ferretti ???). As well as describing the main disturbances to the forest ecosystem, these monographs should suggest the operative procedures to follow in sustainable forest management.

The overall aim of the NFC and the I\&C TF is to optimise collaboration among the Italian participants in the project and between national and international activities, in order to make the maximum contribution possible to the activity of the EU and ICPs. This also in view of the upcoming major revision of study topics, currently being discussed at the level of the European Union (Council and Parliament), which will focus more closely on the ecological aspects of forest research, including essential topics such as the effects of climate change, carbon sequestration and forest biodiversity (proposal of new EU Regulation "Forest Focus"; see EU web site www.europa.eu.int).

\section{REFERENCES}

Alianiello, F., F.A. Biondi, C. Ferrari, G. Mecella \& L. Nisini. 2002. Forest soil conditions in the CONECOFOR Permanent Monitoring Plots and in the Level I Network in Italy. In: Mosello, R., B. Petriccione \& A. Marchetto (Eds), Long-term ecological research in Italian forest ecosystems. J. Limnol., 61 (Suppl. 1): 25-35.

Allavena, S., R. Isopi, B. Petriccione \& E. Pompei. 2001. Programma Nazionale Integrato per il Controllo degli Ecosistemi Forestali. Secondo rapporto 2000. Ministero delle Politiche Agricole e Forestali, D.G. Risorse Forestali, Montane ed Idriche. Roma: $167 \mathrm{pp}$.

Amoriello, T. \& A. Costantini. 2002. Meteorological monitoring and climatological trends in Italian forest ecosystems. In: Mosello, R., B. Petriccione \& A. Marchetto (Eds), Long-term ecological research in Italian forest ecosystems. J. Limnol., 61 (Suppl. 1): 93-99.

Ambrosi, P., A. Bertagnolli, M. Confalonieri, N. La Porta, F. Marchetti, G. Maresi, S. Minerbi, C. Salvadori \& R. Valentinotti. 2002. Eight years of integrated monitoring in Alpine forest ecosystems of Trentino and South Tyrol, Italy. In: Mosello, R., B. Petriccione \& A. Marchetto (Eds), Long-term ecological research in Italian forest ecosystems. J. Limnol., 61 (Suppl. 1): 137-147.

Balestrini, R., A. Tagliaferri, G. Tartari \& F. Di Girolamo. 2002. Forest condition and chemical characteristics of atmospheric depositions: research and monitoring network in Lombardy. In: Mosello, R., B. Petriccione \& A. Marchetto (Eds), Long-term ecological research in Italian forest ecosystems. J. Limnol., 61 (Suppl. 1): 117-128.

Bartolozzi, L., I. Bonini, R. Boretti, F. Bussotti, E. Cenni, A. Chiarucci, A. Cozzi, V. De Dominicis, M. Ferretti, P. Grossoni, G. Landi, C. Leonzio \& G. Vignozzi. 2002. Forest ecosystem monitoring in Tuscany (Italy): past activities, present status and future perspectives. In: Mosello, R., B. Petriccione \& A. Marchetto (Eds), Long-term eco- logical research in Italian forest ecosystems. J. Limnol., 61 (Suppl. 1): 129-136.

Bussotti, F., A. Cozzi, M. Ferretti, E. Cenni, D. Bettini \& R. Nibbi. 2002. Crown condition assessment at the CONECOFOR Permanent Monitoring Plots. In: Mosello, R., B. Petriccione \& A. Marchetto (Eds), Long-term ecological research in Italian forest ecosystems. J. Limnol., 61 (Suppl. 1): 12-18.

Canullo, R., G. Campetella, M.C. Allegrini \& V. Smargiassi. 2002. Management of forest vegetation data series: the role of database in the frame of Quality Assurance procedure. In: Mosello, R., B. Petriccione \& A. Marchetto (Eds), Long-term ecological research in Italian forest ecosystems. J. Limnol., 61 (Suppl. 1): 100-105.

Cecchini, G., S. Carnicelli, A. Mirabella, F. Mantelli \& G. Sanesi. 2002. Soil conditions under a Fagus sylvatica CONECOFOR stand in Central Italy: an integrated assessment through combined solid phase and solution studies. In: Mosello, R., B. Petriccione \& A. Marchetto (Eds), Long-term ecological research in Italian forest ecosystems. J. Limnol., 61 (Suppl. 1): 36-45.

Cutini, A. 2002. Litterfall and Leaf Area Index in the CONECOFOR Permanent Monitoring Plots. In: Mosello, R., B. Petriccione \& A. Marchetto (Eds), Long-term ecological research in Italian forest ecosystems. J. Limnol., 61 (Suppl. 1): 62-68.

Fabbio, G. \& E. Amorini. 2002. Contribution to growth and increment analysis on the Italian CONECOFOR Level II Network. In: Mosello, R., B. Petriccione \& A. Marchetto (Eds), Long-term ecological research in Italian forest ecosystems. J. Limnol., 61 (Suppl. 1): 46-54.

Ferretti, M. 2002. The Integrated and Combined (I\&C) evaluation system to detect status and trends of the CONECOFOR Permanent Monitoring Plots. In: Mosello, R., B. Petriccione \& A. Marchetto (Eds), Long-term ecological research in Italian forest ecosystems. J. Limnol., 61 (Suppl. 1): 106-116.

Manetti, M.C. 2002. Tree ring growth by core sampling at the CONECOFOR Permanent Monitoring Plots. The deciduous oak (Quercus cerris L.) type. In: Mosello, R., B. Petriccione \& A. Marchetto (Eds), Long-term ecological research in Italian forest ecosystems. J. Limnol., 61 (Suppl. 1): 55-61.

Mosello, R., M.C. Brizzio, D. Kotzias, A. Marchetto, D. Rembges \& G. Tartari. 2002. The chemistry of atmospheric deposition in Italy in the framework of the National Programme for Forest Ecosystems Control (CONECOFOR). In: Mosello, R., B. Petriccione \& A. Marchetto (Eds), Longterm ecological research in Italian forest ecosystems. J. Limnol., 61 (Suppl. 1): 77-92.

Marchetti, F., D. Tait, P. Ambrosi \& S. Minerbi. 2002. Atmospheric deposition at four forestry sites in the Alpine Region of Trentino-South Tyrol, Italy. In: Mosello, R., B. Petriccione \& A. Marchetto (Eds), Long-term ecological research in Italian forest ecosystems. J. Limnol., 61 (Suppl. 1): 148-157.

Petriccione, B. \& E. Pompei. 2002. The CONECOFOR Programme: general presentation, aims and co-ordination. In: Mosello, R., B. Petriccione \& A. Marchetto (Eds), Longterm ecological research in Italian forest ecosystems. J. Limnol., 61 (Suppl. 1): 3-11.

Stoddard, J.L. \& T.S. Traaen. 1995. The stages of nitrogen saturation: classification of catchments included in the "ICP on Waters". In: Hornung, M., M.A. Sutton \& R.B. Wilson. Mapping and modelling of critical loads for nitrogen: a workshop report. Proceedings of the Grange-OverSands Workshop, 24-26 October1994. UK Department of Environment and Institute of terrestrial Ecology (Merlewood research Station). 